\section{Effects of nitrogen, calcium and cation exchange capacity on gum yield in Acacia senegal under plantation and savanna woodland conditions in northern Guinea}

\section{savanna, Nigeria}

\section{Unanaonwi OE}

Several reports have indicated fertilizer application is not required for increased gum yield in Acacia senegal. This study investigated the relationships between soil properties and gum yield under plantation and savanna woodland conditions. Multi-stage sampling was used to demarcate a 900 ha plantation into 20 blocks of $45 \mathrm{ha}$, and a 300 ha savanna woodland into 10 blocks of 30 ha. Twenty sub-plots per site were randomly selected for yield assessment by tapping for gum collection, weighing, and recording yield figures in grams. Twelve soil pits were established for soil analysis. Data were analyzed using log-log correlation, and linear regressions. Plantation results showed nitrogen $(r=0.72)$ and Cation Exchange Capacity $(r=0.67)$ were positively correlated with yield, and calcium and yield were negatively correlated $(r=-0.73)$. The plantation results indicated the coefficient of determination $\left(R^{2}\right)$ and standard error (SE) were respectively 0.99 and 0.005 for nitrogen, 0.79 and 0.024 for calcium, and 0.53 and 0.036 for CEC. Ninety-nine percent, $79 \%$, and $53 \%$ of the variation in yield were explained by nitrogen, calcium and CEC, respectively. Under savanna woodland conditions, only nitrogen was positively correlated with yield $(r=0.65)$, and $R^{2}$ and $S E$ were respectively 0.70 and 0.014 , with $70 \%$ of the variation in yield explained by nitrogen. Regression equations were subsequently developed to predict gum yield. Gum yield was correlated with soil chemical properties, and could be predicted based on nitrogen, calcium, and CEC values.

Keywords: gum Arabic, gummosis, nutrient status, Northern Guinea savanna, Sudan savanna

\section{Introduction}

Acacia senegal and Gum Arabic

Acacia senegal (L.) Willdenow (Fabaceae) is a multipurpose tree species highly valued for gum Arabic production. The species ge-

Dept. of Forestry, Wildlife and Fisheries, Nasarawa State University, Lafia Campus, Lafia, Nigeria

(a), Okpo Esio Unanaonwi (okpoesio2002@yahoo.com)

Received: Mar 18, 2010 - Accepted: May 10, 2011

Citation: Unanaonwi OE, 2011. Effects of nitrogen, calcium and cation exchange capacity on gum yield in Acacia senegal under plantation and savanna woodland conditions in northern Guinea savanna, Nigeria. iForest 4: 190-194 [online 2011-0811] URL: http://www.sisef.it/iforest/ show. php?id=587 nerates nearly $90 \%$ of the commercially available grade one gum Arabic. FAO (1990) defines Gum Arabic as the dried exudation from stems and branches of A. sene$\mathrm{gal}$, and closely related species. Gum Arabic is a pale to orange-brown solid, which breaks along a glassy fracture. The best grades are whole, spheroidal-tear shaped, orange brown, with a matt surface texture. It is a nationally and internationally exported commodity. Gum export has been the main stay of the Sudanese economy for over 400 years (Lawal 1998). The commodity was first exported from Nigeria in 1902 under the colonial officers (FDA 2002). Currently, the European Union is the major importer of Nigerian gums, followed by India, and the United States. In pharmaceuticals, it is manufactured in tablet form, where it functions as a binding or coating agent (Glicksman \& Sand 1973). Its primary use is in emulsion stabilization, and tablet and pill formulation. Gum Arabic is also included in cosmetics as an adhesive for masks and powders, and to provide a smooth feel to lotions. Due to its enzyme activity, the gum is not suitable for use in products exhibiting readily oxidizable ingredients. For example, it reduces the Vitamin A content of cod liver oil by $54 \%$ within three weeks (Glicksman \& Sand 1973). In addition, it was formerly administered intravenously to counteract low blood pressure after hemorrhage and surgery, and to treat edema associated with nephrosis. However, these practices caused kidney and liver damage, and allergic reactions, and have therefore been abandoned (Morton 1977). Because gum Arabic is allergen free and lacks dermatological effects, it is preferred for use by the cosmetics industry. It is used in the preparation of glues and adhesives for paper products, and it sometimes serves as a binder for water cement used in foundry. The primary functions of gum Arabic as a technical ingredient include use as a texturizer in sugar and polyols medium; a film former avoiding fat, water and gas migration; a binder for sugar and polyols compressed products; an emulsifier for oil in water emulsion, a carrier for encapsulation; and as a stabilizer for colloidal systems (Omar \& Wasila 1993). In addition, it is used as a sensitizer for lithographic plate solution, to moisten the plates during printing, and as a protector during plate storage. The main function in lithography is to act as a suspending and binding agent. It is also used in the manufacture of matches, ceramic pottery, and as a coating to prevent metal corrosion, among many other applications (DFPC 2002).

\section{Gum Arabic yield}

Yield is a function of soil properties, and site index determines productivity. However, a poor site may be highly productive in terms of yield, but it is dependent on the tree species supported on the site, and the interactions between trees and soil. Soil properties, in part, are responsible for plant growth and yield, in conjunction with other climatic factors. Soil chemical and mineral properties affect yield, i.e., an excess or deficiency of mineral elements can increase or decrease yield.

ASA (2005) reported that calcium provides for normal transport and element retention, and is an essential component of cell membranes and cell walls, therefore serving in structural and stabilizing roles. Phosphate is involved in the formation of oils, starches, sugars, and latex, among other functions; and nitrogen is a component of chlorophyll, the green photosynthetic pigments integral in rapid growth, and increased fruit and seed production (SSSA 2005). SSSA (2005) further reported that potassium regulates ion pumps, and reduces water loss through leaves via stomata, thereby increasing 
drought tolerance. Sap is the fluid carried through xylem tissue. It is a complex emulsion comprised of proteins, alkaloids, starches, sugars, oils, resins, water, and gums (Veatch 2005). Gummosis is a patchy formation of a gummy substance on the surface of certain plants, particularly trees. This typically occurs when sap (technically a latex) oozes from wounds or cankers as a reaction to stimuli, such as adverse weather conditions, infections, and insect attacks, or other mechanical damage. Calcium is a vital element that transports sap or latex to the cell wall, where it is retained and can flow out in liquid form during gummosis. Latex is composed of proteins, alkaloids, starches, sugars, oils, resins, and gum, which are compounds that comprise phosphates; therefore phosphates are a required element in the formation of latex in gum-producing trees such as A. senegal. An environmental characteristic of $A$. senegal, is the capacity to withstand stress despite arid conditions, which is attributed to the role of phosphates. Leaf fall (deciduous habit) is one way of withstanding water stress by plants. Gummosis in $A$. senegal occurs between November and April when environmental conditions become extremely harsh in the Northern Guinea savanna, which is initiated by leaf fall (Morton 1977). Reduced potassium levels in the xylem precede and are present during gummosis, which is also responsible for leaf loss during this period of adverse weather conditions. Yield or productivity is typically an indicator of site quality. Bada (1977) reported site quality is directly demonstrated by stand yield. However, studies conducted by the FDA (2002), FAO/UNEP (1983) indicated that $A$. senegal thrives in the natural savanna woodland environment, and does not require fertilization for gum production However, when the species is cultivated in the rainforest zone, it performs well vegetatively, but does not undergo gummosis. The aims of this study were to assess the effects of nitrogen $(\mathrm{N})$, calcium $(\mathrm{Ca})$, Cation $\mathrm{Ex}$ change Capacity (CEC), and $\mathrm{pH}$ on yield and productivity of gum Arabic under plantation and natural savanna woodland conditions.

\section{Materials and Methods}

\section{Study site}

This study was conducted at Gummi Forest Reserve in Zamfara State, Nigeria. The area is located between Latitudes $11^{\circ} 30^{\prime}$ and $25^{\circ}$ $15^{\prime}$ North, and Longitudes $40^{\circ} 50^{\prime}$ and $70^{\circ}$ 15 ' East. The forest reserve is 300 ha of woodlands within the Gummi Local Government Area of Zamfara State. It is owned and managed for $A$. senegal seed production by the State Department of Forestry. A. senegal is the dominant tree species in the reserve, with pockets of Khaya species (Meliaceae) and scattered $A$. notilica. The plantation is
900 ha in size with $A$. senegal planted at an even spacing of $4 \times 4 \mathrm{~m}$. The plantation was formerly part of the reserve (until 2000), when 900 ha were demarcated for plantation establishment with seeds collected from the reserve.

The region experiences a long dry season from October to May, and a short rainy season from June to September. Two major wind currents coincide with the seasons; the cold easterly occurs during the dry season, and the southwesterly winds during the rainy season. The dry season is characterized by a cold dry period (known as Harmattan) from roughly November to January, followed by a hot dry period from February to April (Singh \& Babaji 1989). Rainfall in the region is unpredictable and limited, with mean annual precipitation of $724 \mathrm{~mm}$. Rainfall patterns exhibit an uneven distribution with a peak in August. The minimum temperature in the coldest month (January), and the maximum temperature in the hottest month (April) fluctuate between $15{ }^{\circ} \mathrm{C}$ and $41{ }^{\circ} \mathrm{C}$, respectively (ZADP 1996).

The state is located within Northern Guinea Savanna. Tall grasses, shrubs, and short scattered woodland trees characterize the vegetation. Common tree species include A. senegal, A. notilica, A. albida, and Khaya spp., among others. These species have experienced bush fires and exploitation over the years.

\section{Plot demarcation and sampling}

A multistage sampling method was applied to compare A. senegal yield and production under plantation and savanna woodland conditions. The entire stand was divided into blocks, and each block was sub-divided into plots. The random-within-block sampling technique was adopted prior to evaluating one plot in each block. The greatest advantage of this technique is that each tree in the stand has an equal chance of sampling, and it provides a means to ensure an even distribution of plots throughout the stands (Becking 1963).

The 900 ha plantation was sectioned into 20 blocks of 45 ha in size. Each block was further divided into $100 \times 100 \mathrm{~m}$ plots. The plots were finally subdivided into $20 \times 20 \mathrm{~m}$ sub-plots, resulting in 25 sub-plots per ha. One randomly selected sub-plot from a randomly selected plot within each block, with a total of 10 sub-plots was selected for yield assessment.

The 300 ha natural woodland was sectioned into 10 blocks of 30 ha in size. Each block was further divided into $100 \times 100 \mathrm{~m}$ plots. The plots were finally subdivided into $50 \times 50 \mathrm{~m}$ sub-plots. Ten sub-plots were randomly selected from a plot randomly selected within each block for yield data collection. From the randomly selected 10 subplots (plots for yield assessment) in the plantation, six sub-plots were randomly chosen for soil sample collection. Six subplots were equally chosen from the 10 subplots (plots for yield assessment) in the savanna woodland for soil sample collection. In the plantation and savanna woodland, six soil pits were established within the same sub-plots selected for yield assessment.

\section{Data Collection}

The yield data collected included the number of trees per sample plot, and gum yield per tree per plot. All standing living trees were recorded. The plantation age at the time of data collection was seven years with a $4 x$ $4 \mathrm{~m}$ space between trees. Based on this spacing, 625 standing trees per ha, or 25 trees per sample plot were expected in the plantation.

Field personnel tapped trees for gum on the same day using short cutlasses, which is a process of cutting holes in the bark to release the exudate. Field personnel were provided a pre-orientation to ensure each individual applied the same tapping skills. Exudates were allowed to dry on the trees, and were hard enough for collection following five weeks. Exudates were weighed (in grams) and yield was recorded on a per tree basis. Code numbers were assigned to each tree in a sampled plot to tally gum yield quantity and respective soil pit as follows:

- YA1-25 T = yield quantity tree numbers 125 , in plot $A$, pit $T$

- YB1-25 M = yield quantity of tree numbers $1-25$, in plot $B$, pit $M$

Data were recorded accordingly.

Bulk soil samples were collected at depths of $1-45 \mathrm{~cm}$. A. senegal has a widely extended lateral root system (Robdorf 1986), therefore the sample depths exhibited a range of depths. Samples $(1 \mathrm{~kg})$ collected from each pit were packed and labeled in plastic containers for laboratory analyses.

\section{Soil analyses}

The following soil properties were analyzed: Acidity $(\mathrm{pH})$, Electrical Conductivity (EC), Nitrogen (N), Phosphorus (P), Potassium $(\mathrm{K})$, Sodium $(\mathrm{Na})$, Calcium $(\mathrm{Ca})$, Magnesium $(\mathrm{Mg})$, Hydrogen $(\mathrm{H})$, Aluminum (Al), Cation Exchange Capacity (CEC), Organic Carbon (OC), Sand, Silt, and Clay.

The laboratory analyses were conducted at the General Science Laboratory, Usmanu Danfodiyo University Sokoto, Nigeria. The soil samples were air-dried, gently crushed in a mortar and pestle, and passed through a $2 \mathrm{~mm}$ sieve. The laboratory experiments performed on fine fractions $(<2 \mathrm{~mm})$ are described below. Separates with sizes $>2 \mathrm{~mm}$ were generally not encountered in view of the fine texture of the soils in the study area.

Particle size analysis was conducted by the hydrometer method (Day 1965). Soil pH was measured in water (1:1 ratio) using a $\mathrm{pH}$ 
meter. Sample OC content was determined following the Walkley et al. (1934) wet-oxidation protocol. The Micro-Kjeldhal digestion-distillation method (Bremner 1965) was used to determine total N. CEC was assessed by saturating $10 \mathrm{~g}$ of soil with normal natural ammonium acetate solution, methanol wash the excess ammonium, and subsequently apply distillation to absorb the ammonium into a boric solution. The distillate was titrated against standard hydrochloric acid. The exchangeable cations were extracted with a $1 \mathrm{M}$ ammonium acetate solution. An EDTA titration method was subsequently used to analyze the extract for $\mathrm{Ca}$ and $\mathrm{Mg}$, and the extract was analyzed with a flame photometer for $\mathrm{K}$ and $\mathrm{Na}$ (BDEA 2006). Available $\mathrm{P}$ and total $\mathrm{AL}$ was determined following Liu (2001). Total K was determined by flame photometry.

\section{Statistical analyses}

Correlation and simple linear regression were employed for statistical analyses using the Statistical Package for Social Scientists (SPSS). The regression equation was determined as follows (eqn.1):

$$
Y=\beta_{0}+\beta_{1} \cdot X+E_{i j}
$$

where $Y$ is the gum yield in gram (dependent variable), $\beta_{0}$ is the regression constant, $\beta_{1}$ is the regression slope, $X$ is the independent variable (soil properties), $E_{\mathrm{ij}}$ is the error.

\section{Results and Discussion}

\section{Plantation}

Maximum gum yield per tree for the ten plots was $115.72 \mathrm{~g}$; the lowest yield figure per tree was $72.55 \mathrm{~g}$, and the mean yield per tree from all samples was $85.09 \mathrm{~g}$. Nitrogen and CEC exhibited a significant $(p<0.05)$ positive correlation with gum yield under plantation conditions, and $\mathrm{Ca}$ showed a significant negative $(p<0.05)$ correlation with yield. The other soil parameters $(\mathrm{pH}, \mathrm{EC}, \mathrm{P}$ $\mathrm{K}, \mathrm{Na}, \mathrm{Mg}, \mathrm{H}, \mathrm{Al}$, organic matter, sand, and silt), though positively associated with gum yield, were not statistically significant (Tab. 1). These results indicated that increased gum yield is strongly associated with increased nitrogen and $\mathrm{CEC}$, and decreased calcium under plantation growing conditions. These results are congruent with Maydell (1983), and Vassal \& Mouret (1989). Veatch (2005) reported the application of nitrogen fertilizer increased rubber (latex) production. The present study suggests nitrogen fertilizer application to A. senegal plantations could increase soil nitrogen status and enhance gum yield.

The relationship between gum yield and nitrogen under plantation conditions was further explained by regression analysis results (Tab. 2), which showed that nitrogen ac-
Tab. 1 - Result of correlation analysis between gum yield and soil properties under plantation. $(*)$ : significant correlation coefficient at $\alpha=0.05$. Maximum gum yield value was $115.72 \mathrm{~g}$; minimum yield was $72.55 \mathrm{~g}$, while the mean yield was $85.09 \mathrm{~g}$.

\begin{tabular}{|c|c|c|c|c|}
\hline Soil properties & $\operatorname{Max}$ & Min & Mean & $\begin{array}{l}\text { Correlation } \\
\text { Coefficient (r) }\end{array}$ \\
\hline $\mathrm{pH}(1: 1) \mathrm{H} 2 \mathrm{O}$ & 7.40 & 6.00 & 6.20 & 0.47 \\
\hline $\mathrm{EC}\left(\mathrm{mS} \mathrm{m}^{-1}\right)$ & 1738.40 & 1340.80 & 1533.20 & 0.47 \\
\hline $\mathrm{N}\left(\mathrm{Cmol} \mathrm{kg}^{-1}\right)$ & 2.36 & 0.30 & 1.45 & $0.72 *$ \\
\hline $\mathrm{P}\left(\mathrm{Cmol} \mathrm{kg}^{-1}\right)$ & 2.84 & 2.51 & 2.63 & 0.11 \\
\hline $\mathrm{K}\left(\mathrm{Cmol} \mathrm{kg}^{-1}\right)$ & 2.45 & 1.75 & 2.11 & 0.47 \\
\hline $\mathrm{Na}\left(\mathrm{Cmol} \mathrm{kg}^{-1}\right)$ & 0.85 & 0.64 & 0.68 & 0.63 \\
\hline $\mathrm{Ca}(\mathrm{Cmol} \mathrm{kg})^{-1}$ & 7.30 & 3.20 & 3.95 & $-0.73^{*}$ \\
\hline $\mathrm{Mg}\left(\mathrm{Cmol} \mathrm{kg}^{-1}\right)$ & 7.40 & 2.53 & 4.30 & 0.62 \\
\hline $\mathrm{H}\left(\mathrm{Cmol} \mathrm{kg}^{-1}\right)$ & 3.72 & 2.35 & 2.75 & 0.03 \\
\hline $\mathrm{Al}\left(\mathrm{Cmol} \mathrm{kg}{ }^{-1}\right)$ & 1.84 & 1.20 & 1.45 & 0.34 \\
\hline $\mathrm{CEC}\left(\mathrm{Cmol} \mathrm{kg}{ }^{-1}\right)$ & 16.10 & 10.20 & 14.30 & $0.67 *$ \\
\hline $\mathrm{OC}\left(\mathrm{g} \mathrm{kg}^{-1}\right)$ & 5.90 & 4.90 & 4.96 & 0.09 \\
\hline Sand $\left(\mathrm{g} \mathrm{kg}^{-1}\right)$ & 540.40 & 305.20 & 439.15 & 0.37 \\
\hline Silt $\left(\mathrm{g} \mathrm{kg}^{-1}\right)$ & 420.45 & 200.10 & 300.60 & 0.04 \\
\hline Clay $\left(\mathrm{g} \mathrm{kg}^{-1}\right)$ & 368.80 & 114.60 & 256.80 & 0.44 \\
\hline
\end{tabular}

counted for $99 \%$ of the variation in gum yield, with an error of $0.005 \%$. The regression coefficient $\left(\mathrm{R}^{2}=0.99\right)$ represents a measure of the degree of reliability in predicting gum yield from nitrogen. Increased gum yield was related to decreased calcium levels in the plantation (Tab. 1). Bush burning is carried out during land preparation in the study area, and adding calcium to the soil, which is not easily leached. Soil $\mathrm{pH}$ level differences were revealed; the savanna woodland soil exhibited a mean acidity level of 6.7, higher than the 6.2 mean determined for the plantation soil. A higher sodium concentration (1.44) in the savanna woodland soil compared with plantation soil $(0.68)$ may be responsible for the $\mathrm{pH}$ differences. Higher soil sodium concentrations will lead to increased acidity, and eventually soil toxicity. Consequently, increases or decreases in gum production will not be observed. The result is consistent with submissions to the ASA (2005). ASA indicated that calcium deficiencies result in inhibition of bud growth, which in A. senegal occur prior to leaf-fall and gummosis. During this period, cessation of apical and bud growth occur in all branches and stems. Due to the complete lack of new leaf and branch production, the entire tree is observed undergoing leaf-fall; consequently leaf-fall enhances gummosis which increases gum yield.

Calcium accounted for $79 \%$ of the variation in gum yield. CEC in plantation soil increased as gum yield increased (Tab. 1) Results demonstrated abundant cations maintained in the soil were advantageous to A. senegal, due to the prevention of leaching and subsequent nutrient retention for plant growth and yield. However, these observations are inconsistent with reports by FDA (2002) and FAO/UNEP (1983), which indicated $A$. senegal thrives on poor sandy soils, loamy sands, and skeletal soils such as lithosols. The implications of these cited works is that $A$. senegal does not require soil nutrients for gum production. However, gum yield is associated with a 53\% increase based on increased soil CEC (Tab. 1).

Sandy soils with low organic matter (OM) have a corresponding low CEC, but clay soils with high OM, have a much greater capacity to hold cations. The relationship between $\mathrm{OM}$ and cations under plantation
Tab. 2 - Results of simple linear regression analysis of gum yield as influenced by Nitrogen, Calcium and $\mathrm{CEC}$ in plantations. The following regression equation was obtained for the prediction of gum yield from Nitrogen, Calcium and CEC under plantation: $\log Y(\mathrm{~g})=A+B$ $\log C\left(\mathrm{Cmol} \mathrm{kg}^{-1}\right)$, where $Y$ is the yield as influenced by $C, \mathrm{~A}$ is the regression constant, $B$ is the regression slope, $C$ is any of the significantly correlated soil properties $(\mathrm{N}, \mathrm{Ca}$ or CEC). $(* *)$ : highly significant $t$ at $\alpha=0.01$.

\begin{tabular}{lccrl}
\hline \multicolumn{1}{c}{$\mathbf{N i} \mathbf{1 0}$} & $\mathbf{B}$ & $\begin{array}{c}\text { Standard error } \\
\text { of B }\end{array}$ & t-value & $\begin{array}{c}\text { P-level } \\
\text { Nitrogen }\end{array}$ \\
\hline Intercept & 3.360130 & 0.0044423 & 759.7802 & $0.0001^{* *}$ \\
LogNt (P) & -0.751777 & 0.023291 & 32.2782 & 0.0001 \\
Calcium Intercept & 3.369138 & 0.02727 & 123.7549 & $0.0001^{* *}$ \\
LogCa (P) & -0.254914 & 0.046416 & -5.4920 & 0.000479 \\
CEC Intercept & 3.467869 & 0.081027 & 42.7988 & $0.0001^{* *}$ \\
LogCEC (P) & 0.230209 & 0.076174 & 3.0221 & 0.016505 \\
\hline
\end{tabular}


Tab. 3 - Result of correlation analysis between gum yield and soil properties under natural forests. Maximum gum yield was $125.28 \mathrm{~g}$, minimum yield was $62.95 \mathrm{~g}$, while the mean yield was 87.67 g. $\left({ }^{*}\right)$ : significant correlation coefficient at $\alpha=0.05$.

\begin{tabular}{lrrrc}
\hline $\begin{array}{c}\text { Soil } \\
\text { properties }\end{array}$ & Max & Min & Mean & $\begin{array}{c}\text { Correlation } \\
\text { Coefficient (r) }\end{array}$ \\
\hline pH $(1: 1) \mathrm{H}_{2} \mathrm{O}$ & 7.05 & 6.45 & 6.70 & 0.05 \\
$\mathrm{EC}\left(\mathrm{Ms} \mathrm{m}^{-1}\right)$ & 812.00 & 684.10 & 791.00 & 0.09 \\
$\mathrm{~N}\left(\mathrm{Cmol} \mathrm{kg}^{-1}\right)$ & 1.60 & 0.49 & 0.73 & $0.65^{*}$ \\
$\mathrm{P}\left(\mathrm{Cmol} \mathrm{kg}^{-1}\right)$ & 2.60 & 2.50 & 2.54 & 0.32 \\
$\mathrm{~K}\left(\mathrm{Cmol} \mathrm{kg}^{-1}\right)$ & 0.95 & 0.49 & 0.91 & 0.19 \\
$\mathrm{Na}\left(\mathrm{Cmol} \mathrm{kg}^{-1}\right)$ & 1.64 & 1.08 & 1.44 & 0.32 \\
$\mathrm{Ca}\left(\mathrm{Cmol} \mathrm{kg}^{-1}\right)$ & 4.12 & 1.85 & 2.05 & 0.06 \\
$\mathrm{Mg}\left(\mathrm{Cmol} \mathrm{kg}^{-1}\right)$ & 3.81 & 0.94 & 1.17 & 0.05 \\
$\mathrm{H}\left(\mathrm{Cmol} \mathrm{kg}^{-1}\right)$ & 3.60 & 2.10 & 2.67 & 0.36 \\
$\mathrm{Al}\left(\mathrm{Cmol} \mathrm{kg}^{-1}\right)$ & 0.70 & 0.14 & 0.28 & 0.05 \\
$\mathrm{CEC}\left(\mathrm{Cmol} \mathrm{kg}^{-1}\right)$ & 12.30 & 7.11 & 10.00 & 0.03 \\
$\mathrm{OC}\left(\mathrm{g} \mathrm{kg}^{-1}\right)$ & 4.82 & 3.51 & 3.80 & 0.17 \\
Sand $\left(\mathrm{g} \mathrm{kg}^{-1}\right)$ & 500.10 & 312.40 & 441.70 & 0.43 \\
Silt $\left(\mathrm{g} \mathrm{kg}^{-1}\right)$ & 482.40 & 211.30 & 334.30 & 0.03 \\
Clay $\left(\mathrm{g} \mathrm{kg}^{-1}\right)$ & 364.60 & 185.20 & 215.00 & 0.02 \\
\hline
\end{tabular}

conditions indicated that with a higher clay value $(r=0.44$, Tab. 1$)$, a higher and significant CEC relationship was observed with yield. The savanna woodland did not exhibit the same r-value observed in the plantation $(\mathrm{r}=0.02$ - Tab. 3).

A. senegal gum yield under plantation conditions can be predicted based on soil N, Ca, and CEC data applying the estimated form of eqn. 1.

\section{Natural savanna woodland}

The savanna woodland showed a significant positive correlation between $\mathrm{N}$ and gum yield $(\mathrm{r}=0.65, p<0.05$, Tab. 3$)$. Maximum gum yield per tree was $125.28 \mathrm{~g}$. The lowest yield value per tree was $62.95 \mathrm{~g}$, and mean yield was $87.67 \mathrm{~g}$ per tree. Increased gum yield is strongly associated with increased soil nitrogen. Soil $\mathrm{pH}, \mathrm{EC}, \mathrm{K}, \mathrm{Ca}, \mathrm{Al}, \mathrm{CEC}$ $\mathrm{OC}$, silt, and clay were not significantly correlated with yield. The relationship between gum yield and nitrogen under natural stand conditions was further explained by the regression results (Tab. 4), which indicated that $\mathrm{N}$ accounted for $70 \%$ of the variation in gum yield, with an error of $0.014 \%$. The regression coefficient $\left(\mathrm{R}^{2}=0.07\right)$ represents a measure of the degree of reliability in predicting gum yield from $\mathrm{N}$. The low clay content $r$-value in the natural savanna woodland resulted in the absence of a correlation

between CEC and yield. This $\mathrm{N}$ observation can be used to predict gum yield under natural stand conditions using eqn.1. The prediction equation will be very useful because most of Nigeria's gum Arabic is harvested from natural savanna woodlands.

\section{Relationships among Nitrogen, Cal-} cium, and Organic Carbon from plantation and natural savanna woodland soils

Plant population dynamics are important factors to consider when assessing organic matter deposition. The species composition comprising different plant populations and the interplay of plant communities will have an affect on the amount and composition of organic matter. Soil litter amounts under plantation conditions were higher than under the natural woodlands of $A$. senegal due to increased tree density is in plantations. $A$. senegal exhibits complete leaf loss during the dry season between November and April in the Northern guinea savanna. This adaptive characteristic results in the addition of large amounts of organic material to the soil, particularly in the plantation where trees are carefully planted at close distances, unlike the savanna woodland where trees exhibit a scanty distribution. The conversion rate of litter to organic elements is slow under natural conditions due to leaching, and soil and

Tab. 4 - Result of simple linear regression analysis of gum yield as influenced by Nitrogen in natural forest. The following regression equation was obtained for the prediction of gum yield from nitrogen under the natural stand: $\log \mathrm{Y}(\mathrm{g})=3.954+0.248 \operatorname{LogNt}\left(\mathrm{Cmol} \mathrm{kg}^{-1}\right)\left[\mathrm{R}^{2}\right.$ $=0.70, \mathrm{SE}=0.014, \mathrm{n}=10]$. (**): highly significant at $\alpha=0.01$; Ni: number of sample; $\mathrm{Nt}$ : nitrogen; N: natural stands.

\begin{tabular}{ccccc}
\hline $\mathbf{N i}=\mathbf{1 0}$ & $\mathbf{B}$ & $\begin{array}{c}\text { Standard error } \\
\text { of } \mathbf{B}\end{array}$ & $\boldsymbol{t}$-value & P-level \\
\hline Intercept & 3.953590 & 0.19251 & 205.3705 & $0.0001^{* *}$ \\
LogNt(N) & 0.247526 & 0.057572 & -4.2994 & 0.0062618 \\
\hline
\end{tabular}

wind erosion. However, the plantation trees are planted close checking both soil and wind erosion, promoting mineralization. This study showed that mean $\mathrm{OC}$ and $\mathrm{N}$ were higher in plantation soil (i.e., a respective 4.09 and 1.45) than the natural savanna woodland (i.e., a respective 3.0 and 0.73 ). These results indicated it is highly unlikely soil $\mathrm{N}$ can ever exceed the $\mathrm{OC}$ in the same soil. Soil N status of a soil therefore depends on the soil carbonic status. Litter addition is low in the natural savanna woodland, which must be noted as a contributing factor for the higher mean soil $\mathrm{N}$ value in plantation soil. Furthermore, similar to most Fabaceae, Robdorf (1986) reported A. senegal undergoes nitrogen fixation, which may increase soil $\mathrm{N}$ levels. Higher tree density under plantation conditions results in increased $\mathrm{N}$ fixation and consequently higher $\mathrm{N}$ levels in plantation soil relative to savanna woodland soils. Mean $\mathrm{Ca}$ values were higher (3.95) in the plantation than savanna woodland (2.05) soils. Vegetation burning prior to plantation establishment (as previously mentioned) could be responsible for higher soil $\mathrm{Ca}$ levels. Furthermore leaching, erosion, litter accumulation, and stand density might increase $\mathrm{Ca}$ levels. Leaching removes the base of topsoil during rains, and is more pronounced on the natural savanna woodland environment due to low tree density than the plantation. In the savanna woodland, the canopy is not closed to "check" the excessive force of rain on the soil, and trees are widely spaced, leading to leaching and erosion, The low and non-correlative mean $\mathrm{Ca}$ value in the savanna woodland resulted in higher mean gum yield compared with the plantation, because the correlative presence of calcium reduced gum yield. However, plantation trees were planted $4 \times 4 \mathrm{~m}$ apart and the root system overlaps between trees as they spread, which keeps the soil intact. Due to increased litter on the savanna woodland floor relative to the plantation, soil erosion and $\mathrm{Ca}$ leaching under plantation conditions was responsible for higher mean soil $\mathrm{Ca}$ values in the plantation, which was further correlated with gum yield. The lack of correlation between gum yield with $\mathrm{Ca}$ in the savanna woodland compared with the correlation under plantation conditions can be further explained by soil CEC conditions. $\mathrm{CEC}$ is a value indicating the capacity for soil to hold cation nutrients, and abundant soil cations prevent leaching. The results showed that the plantation CEC mean value (14.3) was higher than the natural savanna woodland (10.0), serving to explain the higher mean $\mathrm{Ca}$ value, and consequent correlation with yield in the plantation compared to the savanna woodland.

\section{Conclusion}

The dry land species A. senegal is well 
adapted to the harsh, arid conditions of the Guinea, Sudan, and the Sahel savannas. However, for the purpose of increased gum Arabic yield, the species requires changes in soil chemical properties. Yield is positively correlated with nitrogen under plantation and natural savanna woodland conditions, and cation exchange capacity under plantation conditions; and yield is negatively correlated with calcium when grown in the plantation. The results of this study recommend nitrogen fertilizer application to improve gum yield in the plantation and natural savanna woodlands.

\section{References}

ASA (2005). American Society of Agronomy. Agronomy Journal 97: 641-1035. [online] URL: http://www.agronomy.org/

Bada SO (1977). A comparative study of the growth of obeche (Triplochyton sclerenxylon $\mathrm{K}$. Schum.) under plantation and natural forest conditions. M. Phil. dissertation, Dept. of Forest Resources Management, University of Ibadan, Oyo, Nigeria, pp. 89 IX.

BDEA (2006). Soil: scientific characteristics. Berlin, Germany, pp. 120.

Becking RW (1963). Quantities evaluation of plantation communities and IMB condition of phytosociological data. Tropical Ecology 4: 2128.

Bremner MJ (1965). Total nitrogen. In: "Methods of soil analysis", part 1 (Black CA ed). America Society of Agronomy Monograph, No. 9, pp. 371-37x.

Day PR (1965). Particle fraction and particles size analysis. In: "Methods of soil analysis", part 1 (Black CA ed). American Society of Agronomy. Madison, Wisconsin, USA. Agron. 9: 545-567.

DFPC (2002). Factory manual 2002. Dansa food processing company, Kano, Nigeria, pp. 45.

FAO (1990). Gum arabic, gum talha and other Acacia gums. FAO, Rome, Italy.

FAO/UNEP (1983). Notes on trees and shrubs in semi-arid regions. GEMASAK, phase 11, FAO, Rome, Italy.

FDA (2002). Baseline survey on gum arabic. Federal Department of Agriculture, Abuja, Nigeria, pp. 4-10.

Glicksman M, Sand RE (1973). Gum arabic. In: "Industrial gums" (Whistler RL ed). New York Academic Press, NY, USA, pp. 197-263.

Lawal AM (1998). Export marketing of gum arabic. The Nigerian experience. In: Proc. of "Tech. Workshop on Gum Arabic", FDA, Abuja (Nigeria), July 1998.

Liu F (2001). Handbook of environment monitoring for Agriculture. China standards Press, Beijing, China, pp. 699.

Maydell HV (1983). Trees and shrubs of the Sahel; their characteristics and uses. Typo-druk pub., Gmbh, Germany, pp. 41

Morton JF (1977). Major medicinal plants: botany, culture and uses. Charles C. Thomas publi- sher, Springfield, USA, pp. 431.

Omar A, Wasila EK (1993). Gum arabic - an essential non-wood based product in Sudan. Regional Expert Consultation on Non-Wood Forest Products (NWFP) for English-speaking African countries, Arusha, Tanzania.

Robdorf C (1986). Trees and Shrubs of the Sahel, their characteristics and uses. Typo-druk Gmbh, Germany, pp. 101.

Singh BR, Babaji GA (1989). Characteristics of the soils in Bundaya districts. In: "The soils of the University dry land form". Nigerian Journal of Basic Applied Science 3: 7-16.

SSSA (2005). Seedling root growth as a function of soil density and water content. SSSA Journal 69 (6): 1822-1832.

Vassal J, Mouret M (1989). Preliminary results of trials of some Australian Acacia species in southern Corsica (for gum production). Forêt mediterranèenne 11 (2): 113-120. [in French]

Veatch ME (2005). Plant nutrition. Department of Plant Science, University of Arizona, Albuquerque, AZ, USA.

Walkley A, Black IA, Armstrong I (1934). An examination of the Degtjareff method for determining soil organic matter, and a proposed modification of the Chromic Acid titration method. Soil science 37: 29-38. - doi: 10.1097/ 00010694-193401000-00003

ZADP (1996). Handbook. Zamfara State Agricultural Development Project, Ministry of Agriculture, Gusau, Nigeria. 